\title{
Why Would Presbyterians Turn to a Catholic Document?
}

Jay Moses, Hope Presbyterian Church, Wheaton

Dirk Ficca, Interreligious Initiative for Middle East Peace

Nanette Sawyer, Fourth Presbyterian Church, Chicago

Robert Cathey, McCormick Theological Seminary with Jill Folan and Katie Rains

\section{Introduction}

On November 21, 2015, the Assembly of the Presbytery of Chicago meeting at First Presbyterian Church of Lake Forest, Illinois, unanimously adopted in an omnibus motion “'...In our time...' A statement on relations between the Presbytery of Chicago and the Jewish community in metropolitan Chicago."

This statement was the outgrowth of over ten years of dialogue between Jewish and Presbyterian leaders in Chicago that began in September 2004 after conflict occurred between the national Presbyterian Church (U.S.A.) and mainstream Jewish organizations. A majority of Commissioners to the $216^{\text {th }}$ General Assembly of the historic Protestant denomination voted to trigger its investment scrutiny process (MRTI or Mission Responsibility Through Investment) regarding certain corporations that sold hardware or software to the Israeli Defense Force (e.g., Caterpillar Corporation based in Peoria, Illinois, and Motorola Solutions with its headquarters in Chicago).

The MRTI process was intended to discover if any corporations in which the denomination had investments were profiting from the Israeli occupation of Palestinian territories. The Middle East Task Force of Chicago Presbytery (an advocacy organization on behalf of Christians and Muslims in the Near East) supported this General Assembly decision. At the 
same time, the decision presented a challenge to other Presbyterians concerned with interfaith relations among Jews, Muslims, and Christians in global cities like Chicago.

The dialogue of Jewish and Presbyterian leaders that began in Chicago in 2004 focused from the first on the rationale for the General Assembly's action, the nature and implications of MRTI, etc. But by 2006 other questions emerged. What did Presbyterians teach about Jews and Judaism in our theology, sermons, and denominational resources for religious education? One Jewish dialogue partner asked if Presbyterians had ever had a "Nostra Aetate" moment? We replied with references to study papers approved by previous General Assemblies. But in our normative theological documents, The Book of Confessions, there was no one confession that spoke directly and positively to the topics of Jews, Judaism, and their relations with Presbyterians.

The Ecumenical and Inter-Religious Work Group (EIWG) of Chicago Presbytery recognized in 2014 that October 28,2015 , would mark the fiftieth anniversary of the official publication on "...In Our Time..." that radically revised centuries of Roman Catholic teaching and practice (via the Ordinary Magesterium or informal teaching authority of the Church) regarding Jews, Judaism, and other religions. “...In Our Time...” impacted Christians, Jews and others around the world and influenced Presbyterians who wrote The Confession of 1967 and other Presbyterian confessional and study documents.

Recognizing the revolution in human relations sparked fifty years ago by “...In Our Time...”, our Work Group created a sub-committee to draft a document for our time in 2015 that might become a resource for our congregations, institutions, and leaders in our relations with Jews, rabbis and educators, congregations, and institutions in Chicago. On November 10, 2014, we met at McCormick Theological Seminary in Hyde Park, Chicago and began the drafting process. 
In the winter and spring of 2015 we shared early draft versions of our document for constructive critique with members of our Work Group, with leaders from the Jewish United Federation of Chicago, American Jewish Committee, and Chicago Board of Rabbis, specifically with leaders with whom we have been in dialogue since September 2004. We shared a draft version with the Christian Scholars Group for ChristianJewish Relations, an organization founded by the National Council of Churches in 1967 that includes Roman Catholic, Orthodox, Lutheran, United Church of Christ, and Presbyterian scholars and directors of centers for inter-religious relations in the US. I also shared a draft of our document with McCormick students in my "Introduction to Christian Theology" course for their critique.

Chicago Presbytery received a draft of "...in our time...” at the Presbytery Assembly on June 16, 2015, for a first reading. We created a set of discussion questions, divided the Assembly members into small groups, and received oral and written responses from all present, and from other members of Presbytery who wrote to us via email afterwards.

We combined all these responses into a detailed report shared with our Work Group later in the summer. Chicago Presbytery also emailed all other PC (USA) Presbyteries with a draft for their comment and we have read those responses via email. By October we had a new draft that was shared with the Christian Scholars Group meeting at St. Joseph University in Philadelphia and they made detailed comments on all sections.

In light of all the feedback we have received from Presbyterians and others, we revised some of our indicative statements into interrogative form to invite members of Presbytery into an ongoing dialogue with each other and with our neighbors that will continue beyond our Presbytery Assembly of November 2015. 


\section{But why a Roman Catholic document?}

One member of our drafting committee, the Rev. Dr. Jay Moses, a local church pastor ("teaching elder") in Wheaton, Illinois, reflected on Nostra Aetate's significance for Presbyterians:

The social and religious movement known as the Protestant Reformation was a powerful statement and path forward for many in their day, and led to the plethora of different denominational voices that we encounter in our own day. Although the positive repercussions of this movement can be, and have been noted (and as a Presbyterian with Baptist roots it is part of my birthright to recite them from time to time), there was also a great deal lost in the decision to split from the Mother church which can be highlighted in the attempt of these same churches, such as the PC(USA), to relate to larger issues, such as the historic teaching of contempt regarding the Jewish people through Christian history. Specifically, why would a Presbyterian look to a Roman Catholic document such as the groundbreaking Nostra Aetate with regards to articulating a modern day statement to the Jewish people? Two simple reasons can be given here: The unity of the Roman Catholic Church, and her attachment and containment of Christendom tradition.

Protestant traditions are diverse, and they are pluriform. In addition to this, many of the formations of governance, or polity, within them are decentralized, democratic, and organized from the grass roots. There is great similarity in the Presbyterian Church's resemblance to our own United States form of government in regards to the opposition to a top down, "episcopal" type of assemblage. However, what one gains in our freedom of diversity and roots in the "lay" person in the pews, we lose in our ability to speak "as one" to our neighbors around us. As one cannot tell the aver- 
age person's views or local governance's reaction to such Supreme Court actions as our recent "Marriage Equality" issues, so one can see the same difficulty of having "one voice" when a polity such as the PCUSA seeks to speak "as one” regarding such a daunting history and phenomena as anti-Judaic rhetoric and its consequences.

Nostra Aetate gave and gives Presbyterians (and the world) a chance to see what a truly authentic attempt at reconciliation with a neighboring tradition looks like from a religious governance that can speak as one, from the lips of the pope, to the teaching of the church, to the articulation of the priests in the parishes. The Roman Catholic approach of unity through her assemblage shows how a tradition can seek to speak "directly" to the issue with the kind of intention that can be heard by the Jewish people. Although there of course are flaws to any ecclesiastical governance, and although the Roman Catholic "follow through" of what was stated so clearly in Nostra Aetate can be debated, in honesty it is the clearest attempt of a church who can clearly speak "as one." This is highly instructive to those who learn and follow in her wake.

The second reason Presbyterians look to Nostra Aetate and the Roman Catholic church regarding the renouncement of the teaching of contempt and a healing path forward with our Jewish brothers and sisters, is that her organic connection with the history of contempt herself, that is, her close attachment to Christendom tradition. There is no other church that can speak honestly and with greater fullness to the centuries of the articulation of contempt towards Jews than the Roman Catholic Church. The strongest statements and some of the most condemning rhetoric come from within the time period that pre-dated the Reformation itself. This root of error and sin follows a trajectory to the very beginning of Christianity itself. To see a 
Church confessional community, which hold responsibility for the center of this phenomena, turn in repentance and give acts of contrition are uniquely gifts that the Roman Catholic communion witnesses before all who sit at her feet. It speaks in a fullness no one else is able to, but the Church speaks in a revolutionary way in Nostra Aetate which sets the tone for all who follow: to confess and to seek forgiveness is a miraculous sign for others to ponder. In Rome's fullness, her turning is all the more a religious sign of hope for all; "all things are possible with God."

The Presbyterian Church (U.S.A.) is in need of finding the mode (how to speak as one) and the conviction (how to truly take an accounting of her past sins) to speak to the Jewish people. It is a daunting task, and one fraught with great disagreement in a diverse people and a polity that often times does not speak as one. Throughout this time, and especially in our day, the Presbyterian Church looks to the miracles of the past, and the continuance of its intentions in Nostra Aetate, and in its shadow, to speak to the Jewish people, in peace and hopeful healing, in "our time."

Another member of our drafting group with decades of leadership in inner-religious relations, the Rev. Dirk Ficca, wrote:

There are some advantages to having a Pope rather than a corporate and democratic "head of the Church" that we have in the Presbyterian system. A Pope can get all sorts of things done by fiat, and has a "bully pulpit" to advocate for all sorts of other things that needs wider support within the Catholic Church. So if you like what the Pope is doing-such as with Pope Francis-then the ecclesiastic system of the Catholic Church works for you. The downside to this arrangement is, of course, when the Pope is working at cross-purposes to your view of the Church's mission. 
In terms of the groundbreaking nature of Nostra Aetate, the impact of papal initiative has left a lasting legacy. Its profound impact was not only felt within the Catholic Church, marking a shift from Christendommaking the world Christian and Catholic-to the question of what it means to be a Catholic in the world. It also paved the way for other communions in the wider Christian church-catholic with a small c-to do the same, each in their own way.

I would venture to say that there is a sense, at least historically, that Nostra Aetate was first an ecclesiastical act, and then the theological rationale, and its implications for Catholic social teaching, was worked out as time went on, whereas Protestants often have to work out the theological rationale first.

In a practical sense, each and every Catholic diocese has been mandated to have ecumenical and interreligious relations, whatever the personal or theological perspective of the local bishop, clergy, and laity. This has been a major impetus for such relations over time, and has spilled over into the involvement of other Christian communions, as well as the spectrum of diverse religious and spiritual communities.

As I have shared the idea of Chicago Presbytery's '...in our time...' statement with Jews, I’ve been struck by how powerful Nostra Aetate continues to be, not only for more liberal and observant Jews, but also cultural and secular Jews (to use admittedly outsider language). It was liberating for the Jewish community at the time, and still to this day serves as a bulwark against continued suspicions of Jews and Judaism from a religious perspective, as well as against the ebb and flow of antiSemitism.

And for those who are puzzled by why Catholics get a friendlier hearing when they criticize the state of Israel 
along the same lines as Presbyterians and other mainline Protestants, it is Nostra Aetate, and what it means to that relationship, in its affirmation of Jewish identity, that is most often cited as the reason.

With these acknowledgements in mind, we pray the Creator and Redeemer of all things will continue to reform our Church by the Word and Spirit that Jesus of Nazareth communicates among us "...in our time..."

The text of " "...in our time...' A statement on relations between the Presbytery of Chicago and the Jewish community in metropolitan Chicago" follows. Comments and questions may be sent to one of the document's co-authors, Robert Cathey (rcathey@mccormick.edu). 